\title{
KRISIS KOMUNIKASI PADA MASA PANDEMI COVID-19 (Studi Kasus Pemberitaan Penyebaran Covid-19 melalui Udara)
}

\section{Oleh:}

\author{
FERA INDASARI, IDA ANGGRIANI
}

Universitas Dehasen Bengkulu

\begin{abstract}
This study discusses the communication crisis in the mass pandemic Covid-19, a case study in the coverage of the spread of Covid-19 by air. This research uses the theory of SSCT (Situational crisis communication theory) by Choombs, 2007. The method used in this research is descriptive qualitative. the crisis that occurred at WHO could result in the loss of public trust in WHO as a reliable source of world health information, WHO was proven wrong. Based on an understanding of crisis communication, the crisis of the difference in information conveyed by WHO regarding the spread of the corona virus through the air is an information crisis that occurs due to human error, where WHO is considered negligent in reviewing any information before it is submitted to the public. Based on crisis communication theory, WHO is trying to rebuild public trust using the rebuild method, here WHO is rebuilding trust by not condemning the actions of some researchers who think that WHO has been wrong in conveying information to the public, In addition to having acknowledged to the media that based on available evidence regarding the spread of Covid-19 WHO has also not posted information that contains opposition that the corona virus could not be transmitted through the air a few months ago, based on the results of a survey conducted by researchers by checking the WHO Instagram account, and the WHO official website.
\end{abstract}

Keywords: situational crisis communication theory, WHO, Covid-19

\section{PENDAHULUAN}

Dunia saat ini dilanda virus corona yang sudah bermutasi dan dapat mengakibatkan hal yang fatal bagi manusia bukan hanya itu virus tersebut juga menyebar dengan sangat cepat dan mengakibatkan manusia terserang COVID-19 nama penyakit yang diberikan untuk manusia yang terserang virus corona tersebut, sehingga seluruh negeri di penjuru dunia harus menyikapi dengan sigap apa saja yang harus dilakukan agar dapat menghentikan laju penyebaran virus tersebut.

Pada Januari 2020, Organisasi Kesehatan Dunia (WHO) mengumumkan wabah penyakit coronavirus baru di Provinsi Hubei, Tiongkok menjadi Darurat Kesehatan Publik untuk Kepedulian Internasional. WHO menyatakan ada risiko tinggi penyakit coronavirus 2019 (COVID-19) menyebar ke negara lain di seluruh dunia. WHO dan otoritas kesehatan publik di seluruh dunia mengambil tindakan untuk mengendalikan wabah COVID-19. Namun, kesuksesan jangka panjang tidak bisa diterima begitu saja. Semua bagian masyarakat kita termasuk bisnis dan pengusaha- harus berperan jika kita ingin menghentikan penyebaran penyakit ini (WHO.Int di unggah pada tanggal 3 Maret 2020) 
Dapat dipahami bahwa COVID-19 sudah banyak membawa kerugian di seluruh sektor dan bukan hanya sektor kesehatan saja, menurut WHO Semua negara harus mencapai keseimbangan yang baik antara melindungi kesehatan, meminimalkan gangguan ekonomi dan sosial, dan menghormati hak asasi manusia (WHO.Int di unggah pada tanggal 11 maret 2020).

WHO menyatakan bahwa COVID-19 ini bukan hanya krisis kesehatan masyarakat, ini adalah krisis yang akan menyentuh setiap sektor sehingga setiap sektor dan setiap individu harus terlibat dalam perjuangan. Negara-negara harus mengambil pendekatan seluruh pemerintah, seluruh masyarakat, dibangun di sekitar strategi komprehensif untuk mencegah infeksi, menyelamatkan nyawa dan meminimalkan dampak (WHO.Int di unggah tanggal 11 Maret 2020).

Dampak yang besar juga dirasakan di Indonesia, dalam berbagai bidang tetapi banyaknya berita yang simpang siur, bahkan tidak merujuk kepada informasi yang lengkap membuat masyarakat merasa bingung untuk mengikuti berbagai aturan yang dilakukan. masyarakat dibuat takut dengan berbagai headline berita yang memberitakan bagaimana COVID-19 masuk ke Indonesia untuk pertama kali akan tetapi berita yang disajikan tidak lengkap.

Salah satu contoh berita yang membuat masyarakat merasa kurang puas akan informasi yang diberikan salah satunya adalah pemberitaan yang menyebutkan upaya Presiden Joko Widodo mengumumkan dua pasien pertama Covid-19 pada awal maret. Hal ini karena informasi berita kurang akurat dan identitas korban belum terungkap pada saat itu. Berbagai kalangan terus mengkritik pemerintahan terkait dengan tidak jelasnya informasi dan penanganan Covid-19. Masalah komunikasi yang tidak membaik inilah membuat kepercayaan publik menurun.
Masyarakat jadi lebih mempercayai sumber informasi lain dari internet dan media sosial daripada sumber resmi pemerintah, seperti covid.19.go.id dan kemkes.go.id. Padahal sumber informasi lain yang bukan berasal dari web pemerintah seringkali menimbulkan kesimpangsiuran (Suara.com, diunggah pada tanggal 5 Juni 2020).

Berikut juga merupakan pemberitaan baru-baru ini yang mengatakan bahwa corona virus dapat menyebar melalui Udara dilansir dari akuninstagram@Inheartperki 2020.

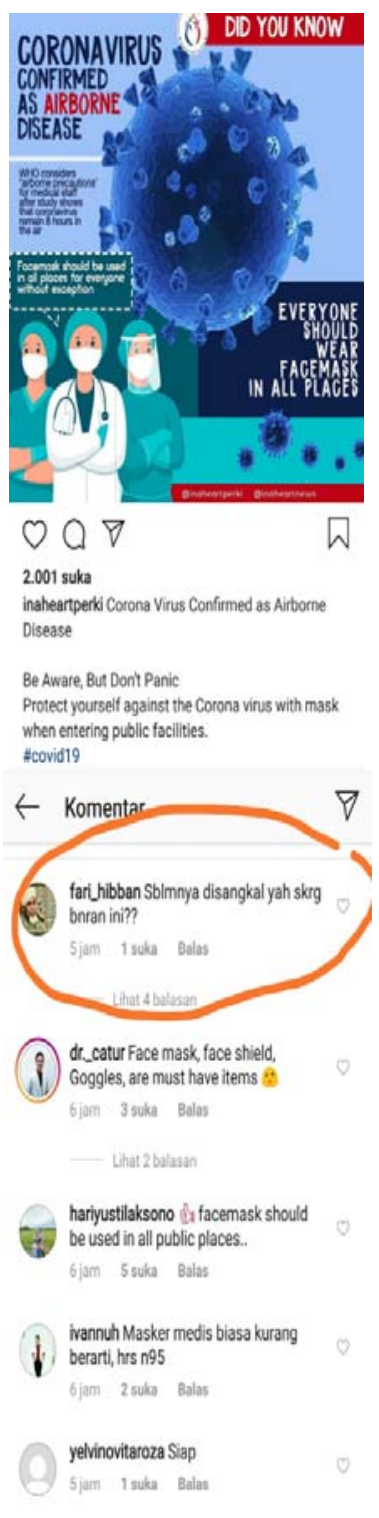


Sebelum menyatakan bahwa corona virus di sinyalir dapat menyebar melalui udara terdapat pernyataan yang sama akan tetapi di tampik oleh WHO dan mengatakan bahwa hal tersebut adalah HOAX, (WHO.Int, yang diunggah pada tanggal 28 Maret 2020).

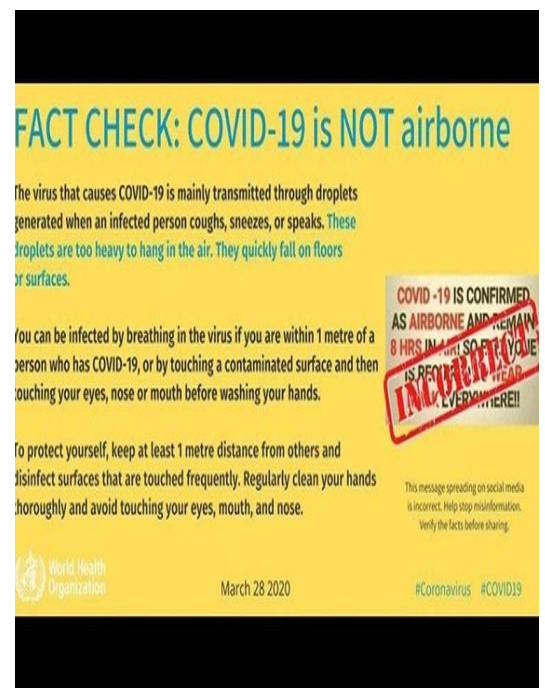

Dari kedua posting WHO tersebut maka masyarakat menjadi semakin sulit untuk memiliki kepercayaan secara utuh kepada media massa, dan keadaan ini haruslah diperbaiki agar masyarakat dapat memahami apa yang benar atau salah dalam pemberitaan tersebut. Selain contoh tersebut tentu masih banyak kasus pemberitaan lain yang membuat masyarakat semakin kesulitan untuk menganalisis informasi yang akurat sehingga peran pemerintah untuk mengevaluasi cara komunikasi yang baik kepada masyarakat tentu harus di lakukan.

Salah satu yang harus dilakukan oleh pemerintah untuk menyampaikan informasi yang dapat diterima oleh masyarakat adalah menggunakan komunikasi krisis. Ilmu komunikasi memiliki peran yang penting dalam membantu menyelesaikan pandemi COVID-19 di Indonesia dan beberapa negara lain. Diantaranya dengan menggunakan komunikasi krisis, ujar Ketua Jurusan Ilmu Komunikasi Fakultas $\begin{array}{lcr}\text { Dakwah dan } & \text { Komunikasi UIN SGD } \\ \text { Bandung, } & \text { Darajat } & \text { Wibawa }\end{array}$ (Ayobandung.com di unggah pada tanggal 12 Juni 2020).

Narayana Mahendra Prastya, dalam jurnalnya "Komunikasi Krisis di Era New Media dan Social Media" (2011), Pinsdorf mengatakan bahwa dasar dari komunikasi krisis adalah memberikan respon dengan segera begitu krisis terjadi, dengan pesan yang terbuka dan jujur kepada para pemangku kepentingan (stakeholder) baik itu yang terpengaruh secara langsung atau tidak langsung. Perusahaan atau organisasi punya waktu "minimal 40 menit hingga maksimal 12 jam" untuk memberikan penjelasan versi mereka atas sebuah krisis. Jika dalam rentang waktu tersebut organisasi atau korporasi gagal merilis informasi yang relevan, maka kepercayaan publik kemungkinan sudah turun terhadap informasi yang akan dirilis di luar time frame tadi

Adapun yang dimaksud dengan komunikasi krisis adalah berkaitan dengan bagaimana organisasi, perusahaan, dan individu mengatasi aspek komunikasi manajemen krisis. bagaimana mereka, atau haruskah mereka, berkomunikasi dengan media berita, karyawan, dan konsumen? mereka harus memilih kata yang mungkin untuk menyampaikan masseges mereka, dan publik atau media yang tepat dan paling tepat. jelas ada lebih banyak metode komunikasi seiring berjalannya waktu. ini pilihan metode yang menantang. namun gagasan dan prinsip tetap melakukan apa yang jauh dan jujur (Fearns-Banks, 2017).

Pada dasarnya krisis dapat terjadi dimana saja, dan pada konteks apa saja, tidak ada satupun lembaga yang kebal dari krisis (Wibawanti Putri Dkk, 2019), begitupula dengan Indonesia khususnya di Kota Bengkulu, pernyataan yang kontroversial dan ambigu dapat menyebabkan masyarakat menjadi salah persepsi, seperti himbauan dari Gubernur yang tidak memperbolehkan masyarakat untuk mengadakan perkumpulan masal yang dilanjutkan oleh aksi Gubernur untuk 
mengadakan buka puasa bersama yang menimbulkan protes masyarakat, dan hilangnya kepercayaan masyarakat terhadap pemerintah.

\section{Komunikasi Krisis}

Komunikasi krisis adalah proses dialog antara perusahaan dengan publik yang dilakukan dengan tujuan untuk menangani krisis yang sedang melanda perusahaan. Strategi dan taktik komunikasi yang digunakan organisasi ketika menghadapi krisis ini dapat memperbaiki citra dan reputasi pasca krisis. Krisis komunikasi terkait dengan penggunaan semua peralatan public relations yang ada, dalam rangka memelihara dan memperkuat reputasi organisasi dalam jangka panjang serta pada waktu ketika organisasi berada dalam kondisi bahaya. Setiap hari, organisasi selalu berhadapan dengan masalah. Keterlambatan pengiriman barang, konsumen yang tidak puas, peluang kerja yang tidak terpenuhi, meningkatnya harga, dan layanan yang kacau adalah beberap tantangan yang sering dihadapi dunia usaha. Namun masalah tersebut tidak selalu berarti mendatangkan krisis kepada perusahaan (Fearn Banks, 2016).

Tujuan komunikasi krisis untuk melindungi dan membela organisasi yang menghadapi tantangan publik untuk reputasinya. kata-kata melindungi dan mempertahankan adalah kata-kata yang sangat kuat. dan komunikasi krisis organisasi harus membantunya mencapai kesinambungan proses bisnis kritis dan arus informasi di bawah krisis, bencana, atau keadaan lain. Secara tradisional, komunikasi krisis tentang melindungi dan membela bukan tentang kebaikan atau kebenaran yang lebih besar. setidaknya ini adalah bagaimana krisis komunikasi telah dirasakan di luar organisasi. tapi ini perlahan berubah. media sosial telah berperan dalam pergeseran ini untuk menjadi lebih terbuka dan transparan (Hurk, 2013).
Sektor publik dan korporasi memiliki perspektif berbeda tentang komunikasi krisis. meskipun mereka berbeda, kedua perspektif itu benar. sektor publik seperti pemerintah memandang komunikasi krisis sebagai cara untuk menyampaikan informasi kepada publik selama masa krisis. organisasi seperti koorporasi memandang komunikasi krisis sebagai cara untuk menyelamatkan reputasi. Sektor publik telah menggunakan media sosial sebagai saluran komunikasi yang valid selama krisis. perusahaan dapat mempelajari bagaimana sektor publik menggunakan media sosial selama krisis (Hurk, 2013).

\section{Kondisi Umum Terjadi Krisis}

Menurut Argenti dalam Prastya (2011) Ada tiga kondisi yang umum terjadi dalam krisis. hal tersebut adalah: (1) elemen-elemen yang sifatnya tak terduga; (2) informasi yang tidak mencukupi; dan (3) begitu cepatnya dinamika yang terjadi, Millar \& Heath dalam Prastya (2011) berpendapat bahwa dalam situasi krisis berita bisa menyebar begitu cepat yang berpotensi melumpuhkan jajaran manajemen sebelum mereka bisa mengontrol situasi dengan efektif. Untuk menjaga citra positif, sebuah korporasi harus menciptakan langkah yang cepat dan efektif saat menghadapi problem apapun, sebab krisis bisa merusak citra paling positif dari sebuah organisasi yang sudah mapan sekalipun.

Cutlip dalam Akhyar dan Pratiwi (2019) mengemukakan tipe-tipe krisis berdasarkan waktu sebagai berikut:

1) Immediate Crisis, atau krisis yang bersifat segera. Tipe krisis ini adalah tipe yang paling ditakuti oleh perusahaan, karena krisis yang terjadi muncul secara tiba-tiba tanpa adanya sinyal-sinyal yang menandakan bahwa krisis akan muncul. Perusahaan juga tidak mempunyai waktu untuk melakukan perencanaan riset. Tipe krisis ini datang dikarenakan adanya 
bencana yang terjadi dan berdampak pada perusahaan. Misalnya, gempa bumi, kebakaran, dan serangan bom. Krisis jenis ini sangat memerlukan konsensus terlebih dahulu untuk level manajemen yang tinggi. Hal ini dilakukan untuk mempersiapkan rencana umum, agar ketika terjadi krisis seperti ini manajemen tidak kebingungan dan setidaknya bisa tahu bagaimana cara menghadapi krisis jenis seperti ini.

2) Emerging Crisis, atau krisis baru muncul. Tipe krisis ini masih memerlukan seorang praktisi PR untuk terlebih dahulu meneliti krisisnya sebelum masalahnya meledak dan dapat membuat perusahaan atau organisasi mengalami kerusakan. Contoh dari tipe krisis ini adalah rendahnya semangat karyawan dalam bekerja, terjadinya pelecehan seksual di tempat kerja, penyalahgunaan jabatan dan lain sebagainya.

3) Sustained Crisis, atau krisis bertahan. Tipe krisis ini adalah krisis yang sudah lama berlalu, tetapi masih saja muncul dalam kurun bulanan atau tahunan. Padahal masalahnya telah diatasi dengan sebaik mungkin oleh pihak manajemen perusahaan. Contoh krisis dari tipe ini adalah spekulasi atau rumor tentang perusahaan yang menyebarluas dari mulut ke mulut, lalu disebarluaskan oleh media massa, sehingga hal ini tidak dapat terkontrol oleh para praktisi PR.

\section{Situational Crisis Communication Theory}

Coombs dan Holladay yang dijabarkan dalam artikel yang diunggah oleh Aruman 2015 mengembangkan Teori yang disebut sebagai Teori Krisis Komunikasi Situasional (Situational Crisis Communication Theory - SCCT) dengan menghubungkan teori atribusi dan analisis restorasi citra analisis. Atribusi adalah bagaimana individu mempersepsikan sumber krisis. Atribusi menciptakan makna untuk menjustifikasi perilakuperilaku tertentu yang mempengaruhi reputasi perusahaan.

Penelitian ini menggunakan SCCT karena dianggap dapat menjabarkan secara rinci bagaimana upaya pemerintah dalam menggunakan komunikasi krisis dalam krisis informasi yang disampaikan oleh WHO mengenai penyebaran virus corona melalui udara khususnya di Kota Bengkulu, sehingga dampak buruk dari krisis tersebut dapat diatasi dengan sigap.

SCCT telah mengembangkan sistem penilaian krisis yang terdiri dari dua tahap, yakni penilaian jenis krisis dan ancaman krisis terhadap reputasi (Coombs dalam Akhyar dan Pratiwi 2019). Jenis krisis ini dibagi menjadi tiga kelompok:

1. Korban, yang merupakan jenis krisis di mana organisasi menjadi korban krisis seperti bencana alam, desas-desus, kekerasan di tempat kerja, kedengkian terhadap organisasi;

2. Tidak disengaja, yaitu organisasi meminimalkan tanggung jawab karena krisis tidak disengaja seperti tantangan, kesalahan teknis, dan bahaya produk;

3. Krisis yang dapat dicegah, yang merupakan krisis yang memungkinkan para pemangku kepentingan untuk sepenuhnya percaya bahwa organisasi harus bertanggung jawab sebagai kesalahan manusia, kelakuan buruk organisasi, kelakuan manajemen, kesalahan organisasi dengan cedera.Tantangan dalam hal ini berarti para pemangku kepentingan mengklaim bahwa organisasi sedang melakukan bisnisnya dengan cara yang tidak pantas.

\section{Krisis Covid-19 Di Bengkulu}

Kasus Covid-19 yang terjadi diseluruh dunia saat ini merupakaan immediete crisis, dimana penyeberan virus corona ke manusia yang di mulai dari China tersebut sangat sulit untuk dikontrol, sehingga menyebabkan seluruh negara di dunia tidak siap untuk menghadapinya dan pada 
akhirnya menyebabkan kematian yang besar pula, tidak terkecuali seluruh daerah di Indonesia, bukan hanya presiden saja tetapi seluruh kepala daerah ikut berperan serta membuat kebijakan masing-masing di daerah pimpinannya agar masyarakat dapat terhindar oleh penyebaran virus corona tersebut khususnya Provinsi Bengkulu.

Berbagai kebijakan yang di buat oleh pemerintah Bengkulu membuat banyak masyarakat terdampak secara psikis maupun dampak materi, berdasarkan berita yang di unggah oleh beritasatu.com 13 April 2020, Sebanyak 1.200 tenaga kerja di Provinsi Bengku terkena pemutusan hubungan kerja (PHK), sebagai dampak pandemi Covid-19. Bukan hanya itu saja masyarakat di Kota Bengkulu juga banyak menerima berita-berita tidak di uji validitasnya sehingga banyak maysrakat yang termakan hoax dan menjadi semakin takut dan melakukan hal-hal yang tidak diharapkan oleh Pemerintah.

Salah satu berita yang membuat masyarakat Bengkulu menjadi bingung adalah pemebritaan mengenai penyebaran virus corona melalui udara, sehingga dapat menginfeksi manusia, di bulan maret WHO menyatakan bahwa virus corona tidak dapat ditransmisi melalui udara dan hal tersebut ditangkal dengan tegas oleh WHO, hingga akhirnya bulan Juni $2020 \quad$ WHO kembali menginformasikan bahwa ternyata virus korona dapat di sebarkan melalui udara.

Organisasi Kesehatan Dunia telah mengakui ada bukti yang muncul bahwa coronavirus dapat disebarkan oleh partikel-partikel kecil yang melayang di udara. Penularan melalui udara tidak dapat dikesampingkan dalam pengaturan yang padat, tertutup atau berventilasi buruk, kata seorang pejabat. Jika bukti dikonfirmasi, ini dapat mempengaruhi pedoman untuk ruang dalam ruangan. Sebuah surat terbuka dari lebih dari 200 ilmuwan menuduh WHO meremehkan kemungkinan penularan melalui udara.
WHO sejauh ini mengatakan bahwa virus ditularkan melalui tetesan ketika orang batuk atau bersin. "Kami ingin mereka mengakui bukti," Jose Jimenez, seorang ahli kimia di University of Colorado yang menandatangani surat kabar, mengatakan kepada kantor berita Reuters (BBC.Com di unggah pada tanggal 8 July 2020).

Hal tersebut menimbulkan berbagai kritik di masyarakat, dimana hal ini dianggap membuat masyarakat semakin terpuruk, dengan adanya kebijakankebijakan yang selalu berubah-ubah serta berita-berita hoax yang tidak diketahui kebenarannya. Maka dari itu pemerintah Bengkulu harus berusaha keras untuk membina masyarakat tanpa membuat masyarakat menjadi semakin terpuruk.

\section{METODE PENELITIAN}

Penelitian ini dilakukan dengan pendekatan ilmiah kualitatif deskriptif. Pendekatan kualitatif adalah suatu metode penelitian yang digunakan dengan tujuan mengeksplorasi, mendeskripsikan, dan memahami suatu gejala secara sentral Creswell (2008). Dengan kata lain, metode penelitian kualitatif digunakan untuk mengkaji, menganalisis, dan meneliti suatu masalah hingga titik di mana masalah itu ditemukan. Penelitian ini berfokus pada deskripsi yang menjelaskan mengenai komunikasi krisis pada masa Pandemi Covid-19 (studi kasus pemberitaan mengenai penyebaran virus corona melalui udara di Kota Bengkulu).

\section{HASIL PENELITIAN DAN PEMBAHASAN}

Berdasarkan pemahaman mengenai komunikasi krisis maka krisis terhadap perbedaan informasi yang disampaikan oleh WHO mengenai penyebaran virus korona melalui udara merupakan krisis informasi yang terjadi karena human error, dimana WHO dianggap lalai dalam mengkaji setiap informasi sebelum disampaikan kemasyarakat. Seharusnya WHO harus memberikan kemungkinankemungkinan secara gamblang jika 
pengujian terhadap informasi belum dapat dipastikan kebenarannya, dan bukan menyangkal informasi yang dianggap belum valid.

Terlepas dari seluruh informasi yang ada pada dasarnya WHO ingin melakukan yang terbaik bagi masyarakat, dan tidak membuat masyarakat yang ada di seluruh dunia menjadi panik, akan tetapi pengabaian terhadap beberapa penelitian oleh WHO justru akan merugikan seluruh masyarakat, karena saat ini masyarakat sangat tergantung dri informasi yang valid dari WHO, dan WHO juga merupakan salah satu organisasi kesehatan dunia yang dipercaya oleh dunia saat ini.

\section{"Kami ingin mereka mengakui bukti"}

Jose Jimenez, seorang ahli kimia di University of Colorado yang menandatangani surat kabar, mengatakan kepada kantor berita Reuters :

"Ini jelas bukan serangan terhadap WHO. Ini debat ilmiah, tetapi kami merasa kami harus mengumumkannya kepada publik karena mereka menolak untuk mendengar bukti setelah banyak percakapan dengan mereka," (BBC.Com, 8 Juli 2020).

Berdasarkan apa yang disampaikan oleh Jose, maka tindakan yang dilakukan WHO saat ini sebenarnya adalah tindakan yang tidak baik, terdapat indikasi bahwa WHO mengabaikan beberapa fakta bahwa virus corona nyatanya dapat ditransmisi oleh udara, maka dari itu berbagai pihak seperti peneliti yang menganggap ini merupakan hal yang penting untuk disampaikan kepada publik harus mendorong WHO untuk tidak mengabaikannya.

Banyak sekali yang menyayangkan hal tersebut terutama masyarakat di Kota Bengkulu, hasil wawancara kepada Jecky seorang mahasiswa Universitas Bengkulu sebagai berikut :
"Aku kemaren lah ngecek kek gaek $a k u$, dak pulo nak takut nian, itu cuma hoax, corona tu dari droplet bukan dari udara, terus ak kasih tunjuk pulo story WHO yang ngecek itu Cuma mith, nah kini dak tahunyo iyo nian itu dari udara jugo, ngeri pulo yak aku, aku lah ngecek kek gaek jangan takut, eh dak tahunyo kini iyo nian, sedih jugo sih kek hal ini, maso WHO salah Informasi.”

Apa yang disampaikan oleh Jecky tersebut nyatanya mengisyaratkan kekecewaan, karena beliau merasa seharusnya WHO tidak melakukan kesalahan dalam menyampaikan informasi tersebut, hal ini akan berdampak bagi orang tuanya, karena beliau sudah mengatakan bahwa corona virus tidak akan menyebar melalui udara berdasarkan postingan WHO, akan tetapi sekarang ternyata WHO mulai mengakui bahwa penyebaran virus melalui udara bisa saja terjadi, dan jecky merasa kesalahan tersebut bisa saja membahayakan masyarakat terutama ibunya.

Pernyataan Jecky diperkuat oleh Farid Mahasiswa Universitas Bengkulu sebagai berikut :

"Oh iyo nian, takut lah rasonyo kini nak kemano-mano, dak do yang benar informasi jaman sekarang, kemaren ngecek dak pacak transmisi lewat udara Cuma droplet ajo, kini lah lain pulo ceritonyo lah pacak pulo transmisi lewat udara".

Farid mengungkapkan kekecewaannya dengan gamblang dimana farid merasa bahwa informasi yang disebarkan mengenai Covid-19 nyatanya masih simpang-siur, tidak ada yang sepenuhnya benar, walaupun penyebar informasinya adalah organisasi yang diakui seluruh dunia dalam menangani hal kesehatan dunia, artinya WHO harus dapat memperoleh solusi yang dapat menyelesaikan krisis kepercayaan 
masyarakat terhadap WHO dengan menggunakan komunikasi krisis.

Berdasarkan teori SSCT sebenarnya krisis yang terjadi terhadap perbedaan pernyataan terdahulu dan sekarang mengenai penyeberan virus korona melalui udara masuk dalam kategori kelompok krisis tidak disengaja, yaitu organisasi meminimalkan tanggung jawab karena krisis tidak disengaja seperti tantangan, kesalahan teknis, dan bahaya produk; dan disini WHO secara tidak sengaja mengesampingkan fakta bahwa ternyata virus korona sebetulnya dapat ditransmisi oleh udara, sehingga timbul krisis kepercayaan dalam diri masyarakat terhadap kapabilitas dan kompetibilitas yang dimiliki WHO dalam menangani virus korona secara serius.

Kesalahan yang di lakukan oleh WHO mengenai bagaimana WHO menentang bahwa virus corona dapat menyebar melalui udara sudah dibuktikan oleh beberapa ahli, dimana beberapa ahli yang meneliti mengenai penyeberan virus korona melalui udara bisa saja terjadi, Beberapa ilmuwan dan peneliti semakin menunjukkan bukti bahwa virus juga dapat ditularkan oleh tetesan yang lebih kecil yang disebut aerosol. Biasanya dihasilkan ketika orang-orang berteriak dan bernyanyi, ini tetap menggantung di udara lebih lama dan dapat melakukan perjalanan lebih jauh. (Aziz, Aljazeera.com, 8 Juli 2020).

Dalam artikel yang ditulis oleh Aziz (Aljazeera.com, 8 Juli 2020) peneliti mengatakan bahwa Corona virus baru dapat bertahan hidup di tetesan dan aerosol hingga tiga jam di bawah kondisi eksperimental, meskipun ini tergantung pada suhu dan kelembaban, sinar ultraviolet dan bahkan keberadaan jenis partikel lain di udara, Stephanie Dancer, seorang konsultan medis ahli mikrobiologi di Inggris, mengatakan kepada Al Jazeera. Aerosol mikroskopis dapat memproyeksikan setidaknya enam meter di lingkungan dalam ruangan, dan mungkin lebih jauh lagi jika arus udara dinamis beroperasi. Jaraknya tergantung pada seberapa besar aerosol itu. Artinya apabila masyarakat tidak waspada terhadap penyebaran korona virus melalui udara tentu saja hal ini akan mengakibatkan semakin banyaknya korban Covid-19 di masa mendatang, apalagi saat ini vaksin masih belum rampung untuk di berikan kepada masyarakat.

Naheed Usmani, Presiden Asosiasi Dokter Keturunan Pakistan di Amerika Utara (APPNA) mengatakan :

"Penularan melalui udara juga dapat terjadi dalam prosedur medis tertentu yang melibatkan pasien yang menghasilkan aerosol, sehingga menempatkan petugas kesehatan pada risiko. Corona virus dapat disebarkan dengan aerosol dalam keadaan khusus jika menggunakan nebuliser, bronkoskopi, intubasi, gigi dan prosedur oral lainnya menggunakan penyedotan dan bilas"

Ini sangat berbahaya bagi petugas kesehatan yang seharusnya hanya mencoba prosedur ini dengan mengenakan alat pelindung diri (APD) yang tepat, termasuk masker N95. (Aziz,ljazeera, 8 Juli 2020).

Berdasarkan teori komunikasi krisis maka WHO berupaya untuk membangun kembali kepercayaan masyarakat dengan menggunakan metode rebuild, disini WHO kembali membangun kepercayaan dengan tidak mengecam tindakan beberapa peneliti yang menganggap bahwa WHO sudah keliru dalam menyampaikan informasi kepada masyarakat, beberapa tindakan dilakukan untuk membangun kembali kepercayaan masyarakat terhadap WHO, dimana WHO telah memberikan pernyataan mengenai kemungkinan bahwa korona virus bisa saja menular melalui udara, berikut salah satu unggahan WHO mengenai transmisi udara dalam penyebaran virus korona. 


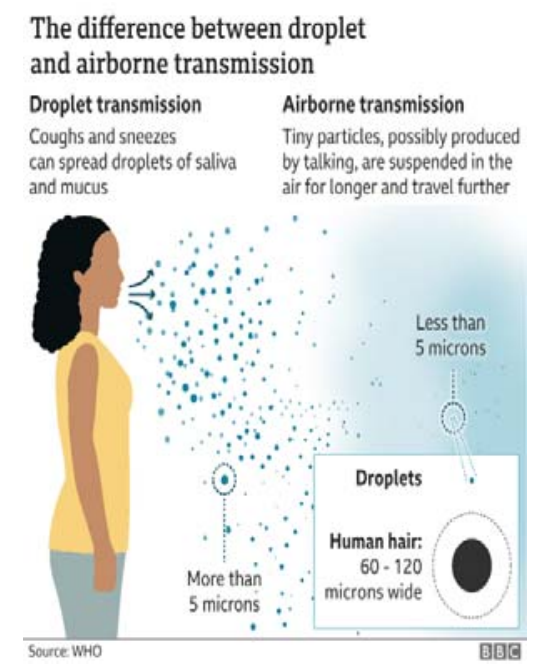

Dalam gambar tersebut WHO berupaya memberikan penjelasan mengenai perbedaan antara penyeberan virus korona melalui droplet dan melalui transmisi udara, dimana penularan virus melalui droplet terjadi dikarenakan adanya batuk, dan bersin oleh penderita Covid-19 karena virus terdapat pada air liur sehingga dengan bersin dan batuk maka liur tersebut akan terpercik kepada orang lain yang memungkinkan penularan Covid-19, sedangkan korona virus yang disebarkan melalui tranmisi udara diakibatkan oleh terdapat partikel yang sangat kecil yang diakibatkan oleh penderita Covid yang berbicara tanpa menggunakan masker, dari postingan tersebut diketahui bahwa WHO mulai menyadari bahwa virus korona juga dapat menyebar melalui udara karena percikan yang sangat kecil yang dapat bergantung di udara untuk beberapa saat.

Terdapat bukti lain bahwa WHO sudah melakukan strategi rebuild dimana WHO sudah menyatakan bahwa WHO mengakui ada bukti yang menunjukkan bahwa ini mungkin dilakukan di pengaturan tertentu, seperti ruang tertutup dan ramai. WHO juga mengatakan bahwa bukti itu harus dievaluasi secara menyeluruh, tetapi jika dikonfirmasi, saran tentang bagaimana mencegah penyebaran virus mungkin harus berubah, dan dapat menyebabkan penggunaan masker yang lebih luas, dan jarak yang lebih ketat, terutama di bar, restoran, dan pada transportasi umum. (BBC.com 8 Juli 2020).

Selain telah mengakui kepada media bahwa berdasarkan bukti yang ada mengenai penyebaran Covid-19 WHO juga sudah tidak memposting informasi yang berisikan penentangan bahwa virus korona tidak dapat transmisi melalui udara bebrapa bulan yang lalu, berdasarkan hasil survei yang dilakukan peneliti dengan mengecek akun instagram WHO, dan website resmi WHO.

\section{PENUTUP}

Krisis yang terjadi pada WHO dapat mengakibatkan hilangnya kepercayaan masyarakat terhadap WHO sebagai sumber terpercaya dalam informasi kesehatan dunia, WHO terbukti melakukan kesalahan dengan Berdasarkan pemahaman mengenai komunikasi krisis maka krisis terhadap perbedaan informasi yang disampaikan oleh WHO mengenai penyebaran virus korona melalui udara merupakan krisis informasi yang terjadi karena human error, dimana WHO dianggap lalai dalam mengkaji setiap informasi sebelum disampaikan kemasyarakat.

Berdasarkan teori komunikasi krisis maka WHO berupaya untuk membangun kembali kepercayaan masyarakat dengan menggunakan metode rebuild, disini WHO kembali membangun kepercayaan dengan tidak mengecam tindakan beberapa peneliti yang menganggap bahwa WHO sudah keliru dalam menyampaikan informasi kepada masyarakat, Selain telah mengakui kepada media bahwa berdasarkan bukti yang ada mengenai penyebaran Covid-19 WHO juga sudah tidak memposting informasi yang berisikan penentangan bahwa virus korona tidak dapat transmisi melalui 
udara bebrapa bulan yang lalu, berdasarkan hasil survei yang dilakukan peneliti dengan mengecek akun instagram WHO, dan website resmi WHO.

\section{DAFTAR PUSTAKA}

Akhyar, M Dhani, Pratiwi, Sekar Arum. 2019. Media sosial dan Komunikasi Krisis : Pelajaran dari Industri Telekomunikasi di Indonesia. Jurnal Ilmu Komunikasi Ultimacomm. ISSN: 2085 - 4609 (Print), e- ISSN 2656-0208. Volume 11 No 1

Banks, Kathleen Fearn. 2016. Crisis Communication : A Casebook Approach. University of Washington

Hurk, Ann Marie Van den. 2013. Social Media Crisis Communication : Preparing for, Preventing, and Surviving. Pearson Education: New york

Prasetya, Narayana Mahendra. 2011. Komunikasi Krisis Di Era New Media dan Media Sosial, Jurnal Komunikasi, ISSN 1907898. Volume 6 No 1. UGM: Yogyakarta

Putril dkk. 2019. Komunikasi Krisis Kementrian Pertanian pada Kasus Penggerebekan Gudang Beras PT Ibu. ISSN: 1978-5003 e-ISSN: $2407-$ 60155 Jurnal Studi Komunikasi dan Media. UNS Indonesia

\section{Sumber Website}

https://www.kompas.com/tren/read/2020/0

3/30/164500565/cek-fakta-who--viruscorona-tak-menular-lewat-udara

https://www.bbc.com/news/world-

53329946 Coronavirus: WHO

rethinking how Covid-19 spreads in

air, di unggah pada tanggal 8 Juli 2020

https://www.beritasatu.com/nasional/6200 53-dampak-covid19-1200-pekerja-dibengkulu-terkena-phk

https://www.who.int/dg/speeches/detail/wh o-director-general-s-openingremarks-at-the-media-briefing-oncovid-19---11-march-2020

https://www.suara.com/yoursay/2020/06/0

5/105213/strategi-memperbaikikomunikasi-krisis-dalam-pusaranpandemi-covid-19 Dewangga Putra Mikola

https://ayobandung.com/read/2020/06/12/9 4253/komunikasi-krisis-untukpandemi-covid-19 Jumat, 12 Juni 2020 13:34 WIB Rizma Riyandi

https://mix.co.id/corcomm-pr/publicrelations/pelajaran-ke-2-dari-airasialevel-crisis-communicationresponsibility. Januari 4, 2015 Edhi Aruman, Pelajaran ke 2 dari AirAsia: Level of Crisis Communication Responsibility 
Jurnal Professional FIS UNIVED Vol.7 No.1 Juni 2020 